\title{
Reduced graphene oxide coating enhances osteogenic differentiation of human mesenchymal stem cells on Ti surfaces
}

Moon Sung Kang ${ }^{1 \dagger}$, Seung Jo Jeong ${ }^{2 \dagger}$, Seok Hyun Lee ${ }^{3}$, Bongju Kim ${ }^{4}$, Suck Won Hong ${ }^{1,3}$, Jong Ho Lee ${ }^{5}$ and Dong-Wook Han ${ }^{1,3^{*}}$ (D)

\begin{abstract}
Background: Titanium (Ti) has been utilized as hard tissue replacement owing to its superior mechanical and bioinert property, however, lack in tissue compatibility and biofunctionality has limited its clinical use. Reduced graphene oxide $(\mathrm{rGO})$ is one of the graphene derivatives that possess extraordinary biofunctionality and are known to induce osseointegration in vitro and in vivo. In this study, rGO was uniformly coated by meniscus-dragging deposition (MDD) technique to fabricate rGO-Ti substrate for orthopedic and dental implant application.

Methods: The physicochemical characteristics of rGO-coated Ti (rGO-Ti) substrates were evaluated by atomic force microscopy, water contact angle, and Raman spectroscopy. Furthermore, human mesenchymal stem cells (hMSCs) were cultured on the rGO-Ti substrate, and then their cellular behaviors such as growth and osteogenic differentiation were determined by a cell counting kit-8 assay, alkaline phosphatase (ALP) activity assay, and alizarin red $S$ staining.

Results: $\mathrm{rGO}$ was coated uniformly on Ti substrates by MDD process, which allowed a decrease in the surface roughness and contact angle of Ti substrates. While rGO-Ti substrates significantly increased cell proliferation after 7 days of incubation, they significantly promoted ALP activity and matrix mineralization, which are early and late differentiation markers, respectively.

Conclusion: It is suggested that rGO-Ti substrates can be effectively utilized as dental and orthopedic bone substitutes since these graphene derivatives have potent effects on stimulating the osteogenic differentiation of hMSCs and showed superior bioactivity and osteogenic potential.
\end{abstract}

Keywords: Titanium, Reduced graphene oxide, Osteogenesis, Bone tissue engineering, Surface coating

\footnotetext{
* Correspondence: nanohan@pusan.ac.kr

${ }^{\dagger}$ Moon Sung Kang and Seung Jo Jeong contributed equally to this work.

'Department of Cogno-Mechatronics Engineering, College of Nanoscience \&

Nanotechnology, Pusan National University, Busan 46241, South Korea

${ }^{3}$ Department of Optics and Mechatronics Engineering, College of

Nanoscience \& Nanotechnology, Pusan National University, Busan 46241,

South Korea

Full list of author information is available at the end of the article
}

(c) The Author(s). 2021 Open Access This article is licensed under a Creative Commons Attribution 4.0 International License, which permits use, sharing, adaptation, distribution and reproduction in any medium or format, as long as you give appropriate credit to the original author(s) and the source, provide a link to the Creative Commons licence, and indicate if changes were made. The images or other third party material in this article are included in the article's Creative Commons licence, unless indicated otherwise in a credit line to the material. If material is not included in the article's Creative Commons licence and your intended use is not permitted by statutory regulation or exceeds the permitted use, you will need to obtain permission directly from the copyright holder. To view a copy of this licence, visit http://creativecommons.org/licenses/by/4.0/ The Creative Commons Public Domain Dedication waiver (http://creativecommons.org/publicdomain/zero/1.0/) applies to the data made available in this article, unless otherwise stated in a credit line to the data. 


\section{Introduction}

Most tissues in the body regenerate over a lifetime, but damage beyond a recoverable range or certain tissues are often irreversibly damaged by internal or external factors such as traumatic injuries, cancers, bacterial or viral infection, and degenerative disease that leads to functional and cosmetic defects. To overcome the issues, tissue engineering has emerged as a promising approach to treat the loss or defectives, thereby improve the wound healing process. Recently, many tissue engineering studies have focused on the development of artificial scaffolds to mimic the structural and functional characteristics of natural extracellular matrix (ECM) [1-5]. Recently developed artificial scaffolds aim to reproduce the physicochemical and mechanical property of natural ECM because the destiny of cells is highly affected by the surrounding microenvironment. Several biofunctional cues such as nanomaterials, biomolecules, and drugs have been incorporated into the scaffold to regulate the cellular behaviors and maintain the intrinsic properties of cells [6-10]. Titanium (Ti) has been utilized as hard tissue replacement such as dentistry, bone, and joint substitutes due to the light but strong mechanical property, durability, non-immune reaction, and nondegradability $[11,12]$. Generally, successful replacement requires hard tissue compatibility for new bone formation and osseointegration, and soft tissue compatibility for epithelial adhesion [13, 14]. However, $\mathrm{Ti}$ has no enough biofunctionality, leading to low interaction with original tissues, and inhibits the adsorption of proteins and cell adhesion. To overcome this issue, surface coating and treatment have been introduced to change the composition, chemical reactivity, and morphology of the $\mathrm{Ti}$ surface while maintaining the suitable mechanical properties of Ti itself [15-19].

On the other hand, graphene is one of the novel nanomaterial family, which is composed of twodimensional monolayered $\mathrm{sp}^{2}$-bonded carbon atoms and features exceptional physicochemical, electrical, and mechanical properties. Graphene and their derivative have been explored increasingly for biomedical applications including drug delivery carriers, imaging probes, biosensors, and tissue engineering scaffolds [20-24]. Graphene is obtained by physicochemical exfoliation of graphite, whereas its derivatives such as graphene oxide (GO), a highly oxidative form of graphene, and reduced GO (rGO), which is prepared by chemical or thermal reduction of $\mathrm{GO}$, have their specific characteristics. The extraordinary biocompatibility of graphene derivatives enables wide application in biomedical fields [25].

In particular, graphene and its derivatives can be utilized as tissue engineering scaffold materials because they have known to enhance cellular behaviors such as adhesion, proliferation, and migration [26-28]. Owing to the hydrophilic and cell-adhesive nature, graphene and its derivatives are utilized as the micro-patterned scaffold to enable contact guidance of cells [29-32]. Furthermore, previous researches indicated that graphene derivatives induce cells to differentiate to specific lineages such as adipogenesis, chondrogenesis, myogenesis, neuritogenesis, and osteogenesis [33-40]. Especially, graphene derivatives such as GO and rGO are known to enhance protein adsorption and cell-cell or cell-matrix interaction, hence, support osteogenic differentiation of pre-osteoblasts and stem cells [41-43]. Compared to GO, rGO possesses structural defects to enhance the interactions with biomolecules, cell, and polymers. Furthermore, by controlling the $\mathrm{C} / \mathrm{O}$ ratio, electrical conductivity and hydrophilicity of the rGO can be precisely tailored to induce optimal cell-matrix interaction responsible for modulating kinds of biological processes [44].

The extraordinary osteogenesis-inducing capability of GO and rGO made them applied as bone tissue engineering scaffold collaborating with kinds of biomaterials such as hydroxyapatite, gelatin hydrogel, calcium phosphate, and RGD peptide [45-49].

In this study, rGO-coated $\mathrm{Ti}$ (rGO-Ti) substrates were fabricated as in vitro culture platform of human mesenchymal stem cells (hMSCs) and to explore their potential as artificial scaffolds for bone tissue engineering. The physicochemical properties of fabricated scaffolds were analyzed by atomic force microscopy (AFM), contact angle measurements, and Raman spectroscopy. Subsequently, the cellular behaviors such as proliferation and osteogenic differentiation of hMSCs on the prepared scaffolds were evaluated.

\section{Methods}

Preparation of rGO nanoparticles (NPs) and rGO-Ti substrate

4000 ppm GO solution was purchased from SigmaAldrich (St. Louis, MO). For the reduction process as described elsewhere [28, 46], GO (1 g) was sonicated in $1 \mathrm{~L}$ deionized water for $2 \mathrm{~h}$. Hydrazine hydrate $(10 \mathrm{~mL})$ was then added to the suspension and the reaction proceeded at $100{ }^{\circ} \mathrm{C}$ for $24 \mathrm{~h}$. After the reaction, the suspension was filtered and washed several times with water/ ethanol solution. Finally, the rGO NPs were prepared after drying in a vacuum oven at $80^{\circ} \mathrm{C}$ for $12 \mathrm{~h}$.

As shown in Fig. 1, rapid film deposition was achieved using the meniscus-dragging deposition (MDD) technique [42]. The $\mathrm{Ti}$ substrates were used as a deposition plate and a coating plate. They were cleaned with a piranha solution for $30 \mathrm{~min}$ and rinsed with deionized water. This is a short time process; the deposition plate was placed on the coating substrate at an angle of $30^{\circ}$ 


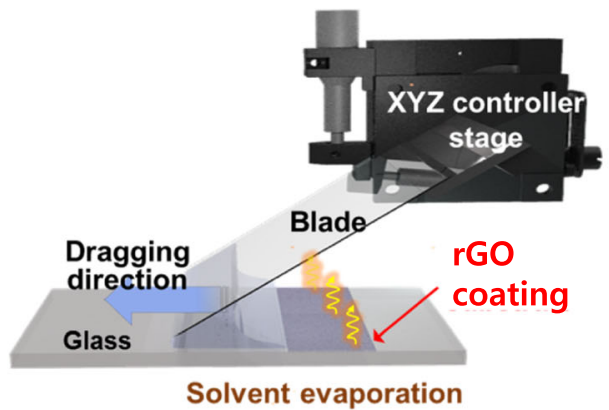

Solvent evaporation

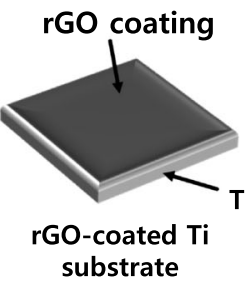

Osteogenesis Stimulating i substrate

hMSC

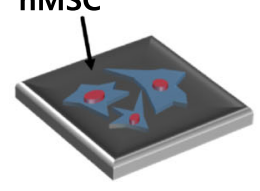

In vitro Cell culture

\section{Bone Tissue engineering}

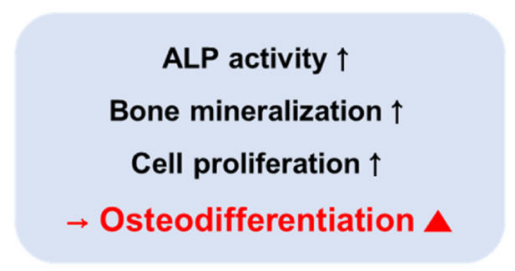

Osteogenic differentiation

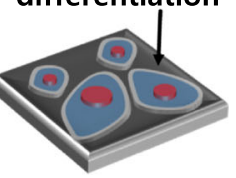

and a $50 \mathrm{~mL}$ droplet of the rGO solution was injected into the wedge between the two plates. The deposition plate was pushed linearly in an alternating back-andforth motion (one alternating motion is defined as one deposition number) by a motorized stage (AL1-15153S, Micro Motion Technology, Valley Center, USA) at a constant speed of $250 \mathrm{~mm} / \mathrm{s}$ to deposit the rGO on the coating substrate. The coating area of the rGO-Ti membranes was $5 \times 5 \mathrm{~cm}^{2}$. The large-area rGO thin films on the $\mathrm{Ti}$ substrate were coated with a rGO concentration of $100 \mu \mathrm{g} / \mathrm{mL}$. Subsequently, the rGO-Ti membranes were dried at $80^{\circ} \mathrm{C}$ for $30 \mathrm{~min}$.

\section{Characterizations of intact $\mathrm{Ti}$ and $\mathrm{rGO}-\mathrm{Ti}$ substrate}

Intact $\mathrm{Ti}$ and $\mathrm{rGO}-\mathrm{Ti}$ substrates were washed with acetone and DPBS three times respectively and dried at RT for every experiment in this section. Intact $\mathrm{Ti}$ and $\mathrm{rGO}-$ Ti substrates were imaged by AFM (XE-100, Park Systems) with a silicon cantilever in non-contact mode. The images with $10 \mu \mathrm{m} \times 10 \mu \mathrm{m}$ scan sizes consisted of $512 \times$ 512 points of height data and a scan rate of $1.0 \mathrm{~Hz} /$ line. $R_{\mathrm{q}}$ represents the root mean square value of the height raised from the standard when filling a lower valley from a height higher than the standard. $R_{\mathrm{q}}$ values were calculated with three separate samples at various location as follow:

$$
R_{q}=\sqrt{\frac{1}{l} \int_{0}^{l} y^{2}(x) d x}
$$

Raman spectra of intact $\mathrm{Ti}$ and $\mathrm{rGO}-\mathrm{Ti}$ substrates were recorded using a Raman spectroscopy (Ramboss 500i, Dong Woo Optron Co., Gwangju, Korea) equipped with a charge-coupled device camera (iDusDV420A-OE,
Andor Technology, Belfast, Ireland) and a precise motorized stage (SGSP 20-85, Sigma Koki Co., Ltd., Tokyo, Japan). Ar-ion laser of $532 \mathrm{~nm}$ (LasNova 50, LASOS, Jena, Germany) was focused on the sample using a water immersion objective lens ( $\times 60$ magnification, the numerical aperture of 1.2 UPlanSApo, Olympus, Tokyo, Japan) and resolved with a monochromator (Monora500i, DongWoo Optron Co., Gwangju, Korea). $5 \mathrm{~mW}$ laser power at $532 \mathrm{~nm}$ that is attenuated by using a neutral density filter of $50 \%$ transmittance at the objective was used at a range of $1300-2900 \mathrm{~cm}^{-1}$. Water contact angles of the intact $\mathrm{Ti}$ and $\mathrm{rGO}-\mathrm{Ti}$ substrates were measured the sessile drop method using the OCA 10 goniometer (Dataphysics, Filderstadt, Germany). The $10 \mu \mathrm{L}$ of distilled water was dropped onto the surface of the intact $\mathrm{Ti}$ and rGO-Ti substrates and the images were captured, thereafter, the contact angle was calculated by an optical system.

\section{Cell culture and conditions}

hMSCs were purchased from Lonza (Walkersville, MD, USA), and all experiments were conducted using hMSCs between passages 3 and 5. To maintain undifferentiated state, hMSCs were routinely cultured in MSC basal medium (Lonza) containing 10\% of MSC growth supplement (Lonza), $2 \%$ of l-glutamine, $0.1 \%$ of GA-1000, and $1 \%$ of antibiotic-antimycotic solution (10,000 units of penicillin, $10 \mathrm{mg}$ of streptomycin, and $25 \mu \mathrm{g}$ of amphotericin B per mL, Sigma-Aldrich) at $37^{\circ} \mathrm{C}$ under $5 \% \mathrm{CO}_{2}$ in a humidified atmosphere. For osteogenic differentiation assay, hMSCs were cultured in Dulbecco's modified Eagle's medium (DMEM) supplemented with $10^{-8}$ $\mathrm{M}$ dexamethasone (Abcam), $0.2 \mathrm{mM}$ ascorbic acid 
(Sigma-Aldrich), and $10 \mathrm{mM} \quad \beta$-glycerolphosphate (Sigma-Aldrich).

\section{Cell proliferation assay}

To evaluate the proliferation of hMSCs on intact Ti and rGO-Ti substrates, a cell counting kit-8 (CCK-8) assay (Dojindo Laboratories, Kumamoto, Japan) was performed according to the manufacturer's protocol. hMSCs were seeded at a density of $1 \times 10^{4}$ cells $/ \mathrm{mL}$ on $10 \times 10 \mathrm{~mm}^{2}$ intact $\mathrm{Ti}$ and rGO-Ti substrate, and cultured at $37{ }^{\circ} \mathrm{C}$ under $5 \% \mathrm{CO}_{2}$ in a humidified atmosphere. After 1, 7, 14, and 21 days of incubation, each sample was washed twice with DPBS solution, and then cultured with a CCK-8 solution for $2 \mathrm{~h}$ at $37{ }^{\circ} \mathrm{C}$ in the dark under $5 \% \mathrm{CO}_{2}$ in a humidified atmosphere. The absorbance at $450 \mathrm{~nm}$ was assessed at each time point by using a SpectraMax 340 plate reader (Molecular Devices Co., Sunnyvale, CA, USA).

\section{Alkaline phosphatase (ALP) activity assay and alizarin red $S$ (ARS) staining}

To investigate the osteogenic differentiation of hMSCs, ALP activity assay was conducted. The hMSCs were seeded at a concentration of $1 \times 10^{4}$ cells $/ \mathrm{mL}$ on intact Ti substrate and rGO-Ti substrate and incubated for 1 , 7, 14, and 21 days. ALP activity of hMSCs was determined by measuring the conversion of $\rho$-nitrophenylphosphate to $\rho$-nitrophenol by an ALP assay kit (Abcam, Cambridge, UK) as per the manufacturer's protocol. The absorbance at $405 \mathrm{~nm}$ was assessed at each time point by using a SpectraMax 340 plate reader. ALP activity was estimated by calculating the total amount of $\rho$ nitrophenol formation $(\mu \mathrm{mol})$ divided by the reaction time (min) and volume of sample (mL) (OD value*1000/ $60 / 0.24)$.
To monitor the extracellular calcium deposits of hMSCs, the cells were seeded at a concentration of $1 \times$ $10^{4}$ cells $/ \mathrm{mL}$ on intact $\mathrm{Ti}$ substrate and $\mathrm{rGO}-\mathrm{Ti}$ substrate and incubated for 1, 7, 14, and 21 days. At each time point, hMSCs were washed twice with DPBS solution, fixed with $3.7 \%$ of formaldehyde for $10 \mathrm{~min}$, and stained with $40 \mathrm{mM}$ of ARS in DPBS solution ( $\mathrm{pH} 4.2$, Sigma-Aldrich). The hMSC-cultured substrates were imaged with a digital camera (Olympus Optical Co., Tokyo, Japan). Quantitative analysis was performed by extracting ARS in stained hMSCs. To extract ARS from stained hMSCs, $10 \%$ of acetic acid solution was added, and hMSC-cultured substrates were incubated for $30 \mathrm{~min}$ with constant shaking at $80 \mathrm{rpm}$. After then, $10 \%$ of ammonium hydroxide solution was added to neutralize the aqueous solution of the ARS extracts, and the absorbance values were measured using a SpectraMax 340 plate reader at $405 \mathrm{~nm}$.

\section{Statistical analysis}

All variables were tested in three independent cultures for each experiment, which was repeated twice $(n=6)$. The quantitative data are expressed as the mean \pm standard deviation (SD). The data were tested for the homogeneity of the variances using the Levene test, before statistical analysis. Statistical comparisons were carried out using a one-way analysis of variance (ANOVA; SAS Institute Inc., Cary, NC), followed by a Bonferroni test for multiple comparisons.

\section{Results}

Physicochemical properties of intact $\mathrm{Ti}$ and $\mathrm{rGO}-\mathrm{Ti}$ substrates

Surface characteristics of prepared intact $\mathrm{Ti}$ and $\mathrm{rGO}-\mathrm{Ti}$ substrates were characterized. As shown in Fig. 2a and c,

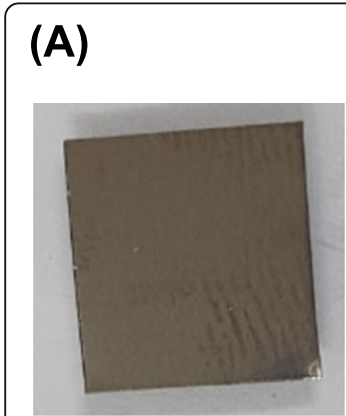

(B)

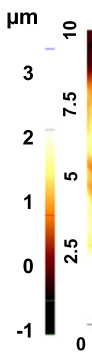

(C)

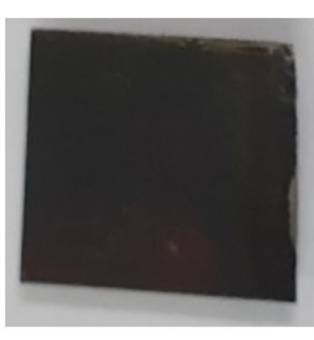

(D)

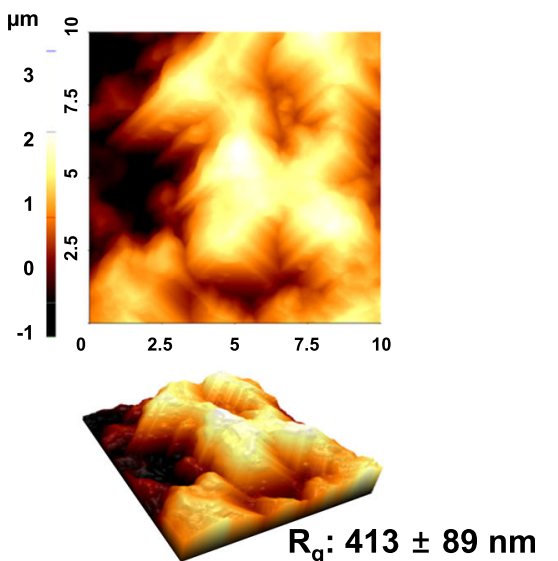

Fig. 2 Surface characteristics of intact Ti and rGO-Ti substrates. Digital images of a intact Ti and $\mathbf{c}$ rGO-Ti substrates. AFM images of $\mathbf{b}$ intact Ti and $\mathbf{d}$ rGO-Ti substrates 


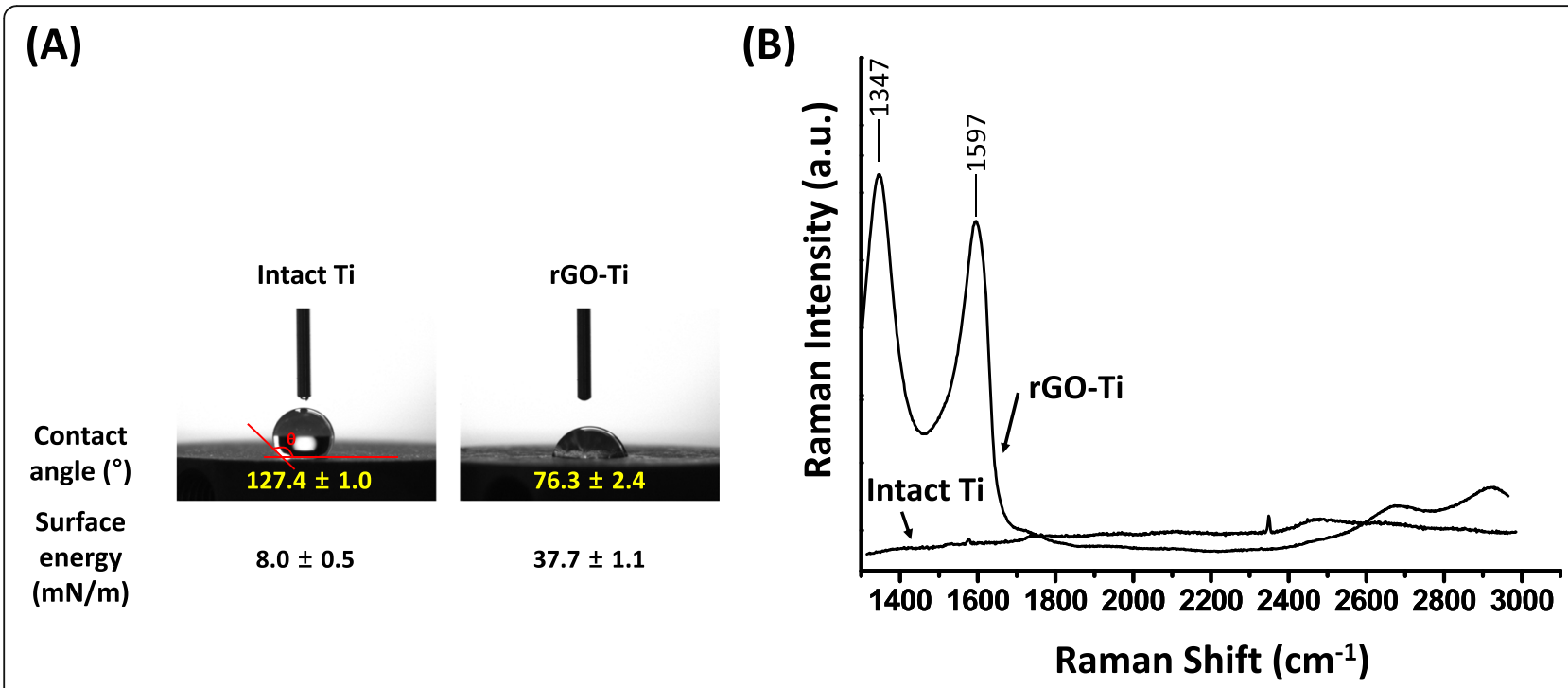

Fig. 3 Physicochemical properties of intact Ti and rGO-Ti substrate. a Contact angle and $\mathbf{b}$ Raman spectra of intact Ti and rGO-Ti substrates

the rGO-Ti substrates have darker surface than intact $\mathrm{Ti}$ showing rGO was uniformly coated on the Ti surface. Figure $2 \mathrm{~b}$ and $\mathrm{d}$ indicate the representative AFM images and height profile of intact $\mathrm{Ti}$ and $\mathrm{rGO}-\mathrm{Ti}$ substrates. Both substrates have a microscopically rough surface with a height $\leq 4 \mu \mathrm{m}$. In particular, the $\mathrm{R}_{\mathrm{q}}$ value of rGO$\mathrm{Ti}$ is relatively lower than that of intact $\mathrm{Ti}$ indicating the surface of rGO-Ti substrates with micro-scale grooves was partially flattened after nano-scale rGO NPs had been coated on them.

Fig. 3 represents the physicochemical property of intact $\mathrm{Ti}$ and $\mathrm{rGO}-\mathrm{Ti}$ substrates. Water contact angle measurements (Fig. 3a) indicate the contact angle and surface energy of intact $\mathrm{Ti}$ and $\mathrm{rGO}-\mathrm{Ti}$ substrate. Contact angle and surface energy of $\mathrm{rGO}-\mathrm{Ti}$ was $76.3^{\circ} \pm 2.4^{\circ}$ and $37.7 \pm 1.1 \mathrm{mN} / \mathrm{m}$, while that of intact $\mathrm{Ti}$ was $127.4^{\circ} \pm 1.0^{\circ}$ and $8.0 \pm 0.5 \mathrm{mN} / \mathrm{m}$, respectively. The result indicated that $\mathrm{rGO}-\mathrm{Ti}$ substrates are more hydrophilic than intact Ti substrates. However, it is a specific characteristic of rGO to have structural defects and retain residual oxygen moieties such as hydroxyl groups, carbonyl groups, carboxylic groups, and epoxide from graphene oxide. In other words, by maintaining the hydrophobic property of intact graphene to some extent, rGO potentially encourages the cells to adhere to the surface. A previous study compared the water contact angle between $\mathrm{GO}$ and $\mathrm{rGO}$, indicating $\mathrm{GO}$ is hydrophilic while rGO is very hydrophobic. rGO-Ti substrates of our results are not very hydrophobic (water contact angle of $\mathrm{rGO}$ is $<90^{\circ}$ ), which attribute to the highly smoothed surface morphology [50].

Raman spectra revealed that intact $\mathrm{Ti}$ substrates did not exhibit any specific Raman peak indicating that there are no impurities on the prepared sample (Fig. 3b).
Whereas, rGO-Ti substrates exhibited strong Raman peaks at $1347 \mathrm{~cm}^{-1}$ and $1597 \mathrm{~cm}^{-1}$. These peaks are characteristic Raman spectra of carbon nanomaterials, D band $\left(\sim 1350 \mathrm{~cm}^{-1}\right)$, and $\mathrm{G}$ band $\left(\sim 1600 \mathrm{~cm}^{-1}\right)[51,52]$. $G$ band depicts the hybrid carbon from the graphene and $\mathrm{D}$ band derived from the structural defects from $\mathrm{sp}^{2}$ hybrid carbon [53, 54]. Results indicated that the Raman intensity ratio of $\mathrm{D}$ band and $\mathrm{G}$ band $\left(\mathrm{I}_{\mathrm{D}} / \mathrm{I}_{\mathrm{G}}\right)$ was 1.11 , corresponding general $\mathrm{I}_{\mathrm{D}} / \mathrm{I}_{\mathrm{G}}$ value of $\mathrm{rGO}$ which is larger than 1 . Therefore, it is considered that $\mathrm{rGO}$ was successfully prepared and coated on Ti substrates.

Proliferation of hMSCs on intact Ti and rGO-Ti substrates The growth and proliferation of hMSCs on the boneimplant surface play a crucial role in osseointegration with original tissues. Thus the effect of rGO-Ti substrates on the growth of hMSCs was evaluated quantitatively. Fig. 4 shows the proliferation of hMSCs assessed by CCK- 8 assay. After culturing hMSCs on intact Ti and rGO-Ti substrates, cell proliferation was assessed at days $1,7,14$, and 21. Both intact $\mathrm{Ti}$ and $\mathrm{rGO}-\mathrm{Ti}$ substrates showed a tendency to enhance cell proliferation. At 1 and 3 days of incubation, cell proliferation on $\mathrm{rGO}-\mathrm{Ti}$ slightly increased compared to intact $\mathrm{Ti}$ substrates. On day 14 and 21 , the proliferation of hMSCs on rGO-Ti substrates was significantly $(p<0.0001)$ increased compared to that of intact Ti substrates.

\section{ALP activity of hMSCs on intact Ti and rGO-Ti substrates}

Osteoblastic cells secrete ECM proteins and early differentiation markers such as ALP, which plays an important role in bone matrix deposition and mineralization by providing calcium and phosphate ions. To evaluate the osteogenic differentiation promoting the ability of $\mathrm{Ti}$ - 


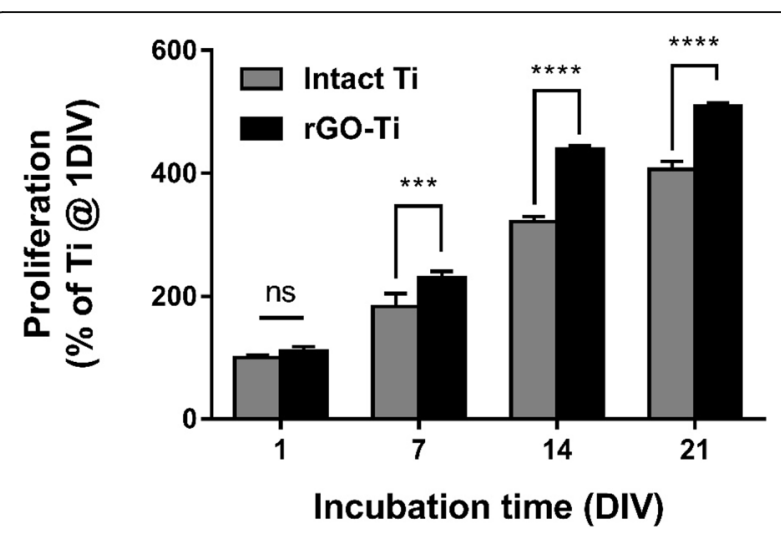

Fig. 4 hMSCs proliferation on intact Ti and rGO-Ti substrates. The results are shown as the mean \pm SD ( $n=6$, ns: not significant, ${ }^{* * *}$ : $\left.p<0.001{ }^{* * * *}: p<0.0001\right)$

rGO substrates, ALP activity of hMSCs was assessed. Figure 5 shows the ALP activity of hMSCs on intact Ti and rGO-Ti substrates after $1,7,14$, and 21 days of incubation. Both intact Ti and rGO-Ti substrates showed the highest ALP activity at 14 days and tend to decrease at 21 days. ALP is one of the early markers of osteogenic differentiation, therefore, increases in the stage of osteogenesis and decreased when MSCs differentiate to osteocytes [55]. In particular, hMSCs showed significantly $(p<0.01)$ increased ALP activity at 14 and 21 days compared to that of intact Ti substrates. These results may be attributed to defective structure and the oxygen moieties of rGO which enhanced cell-matrix interaction and essential protein adsorption from serum.

\section{Mineralization of hMSCs on intact Ti and rGO-Ti substrates}

To further explore the osteogenic differentiationinducing effect of rGO-Ti, calcium phosphate deposition

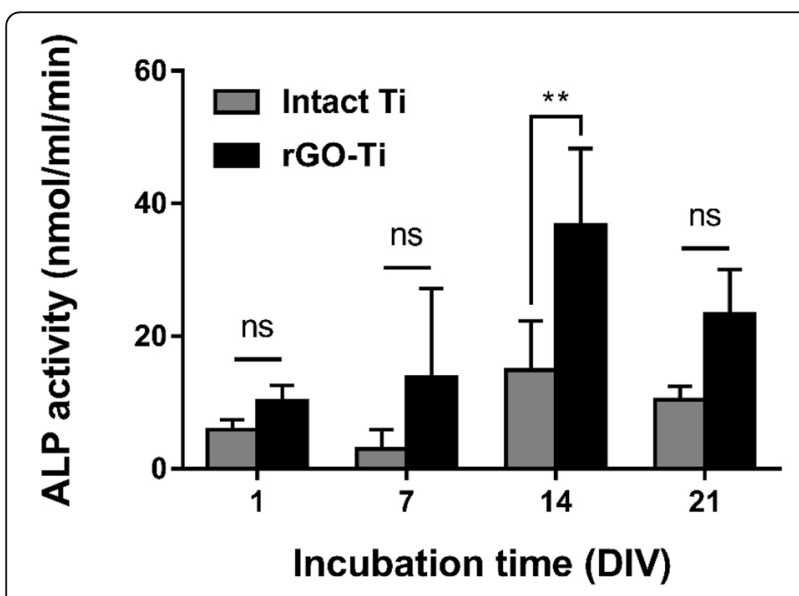

Fig. 5 ALP activity of hMSCs on intact Ti and rGO-Ti substrates. The results are shown as the mean \pm SD $(n=6$, ns: not significant, **: $p<0.01$ ) which is considered as a later marker for bone regeneration was observed by ARS staining. The image of ARS staining (Fig. 6a) and its corresponding graph (Fig. 6b) showed that rGO-Ti substrates significantly $(p<0.0001)$ increased extracellular calcium deposition in hMSCs, which was stained in red. While there was no significant difference between intact $\mathrm{Ti}$ and $\mathrm{rGO}-\mathrm{Ti}$ substrates at 1 day, the notable formation of calcium deposits was observed on rGO-Ti substrates from 7 to 21 days. These findings suggest that $\mathrm{rGO}$ can induce an osteoid matrix deposition even without any osteogenic inducing agents.

\section{Discussion}

In the present study, it was investigated whether rGO coating on Ti substrates can enhance the osteogenic differentiation of hMSCs without hindering cell growth for potential applications to bone tissue engineering and regeneration. To testify this hypothesis, the rGO-Ti substrates were prepared by the MDD process, which coats the intact surface of Ti substrates uniformly. After rGO coating, it was found that the Ti substrates showed a decrease in their surface roughness and water contact angle. Many studies have emphasized that surface roughness influences cell adhesion and regulates integrin-mediated signal cascades [56-58]. Moreover, rough surface enhances biomolecules adsorption, which can promote osteoblastic differentiation of hMSCs. A previous study reported the effects of Ti substrates with a different surface roughness on osteogenesis of SaOS-2 osteoblast-like cells [59]. SaOS-2 cells showed increased ECM protein synthesis and integrin protein expression on a rough surface, indicating accelerated cell-matrix adhesion according to surface roughness. Consequently, ALP activity was highly increased on the rough surface while there was no significant increase on the smooth surface [59]. However, the correlation of surface roughness and superficial morphology to enhanced osteogenesis of hMSCs is still controversial. Another study compared cell growth and expression of osteogenic markers of MG63 osteoblast-like cells according to the different surface roughness. Several markers such as ALP level, osteocalcin, procollagen type I, Transforming growth factor $ß 1$ (TGF $ß 1$ ), and nitrogen oxide level showed unrelated tendency according to the surface roughness [60]. These results suggest that various cell signaling are concerning osteogenesis, therefore, which means that it needs comprehensive correlation between the mechanisms of bone formation at the implant surface, the effects of the material on the surrounding cells and the profile of cytokines, growth factors, and other local mediators [61]. On the other hand, the wetting performance of the scaffold is critically important in bone tissue engineering because it directly determines the 


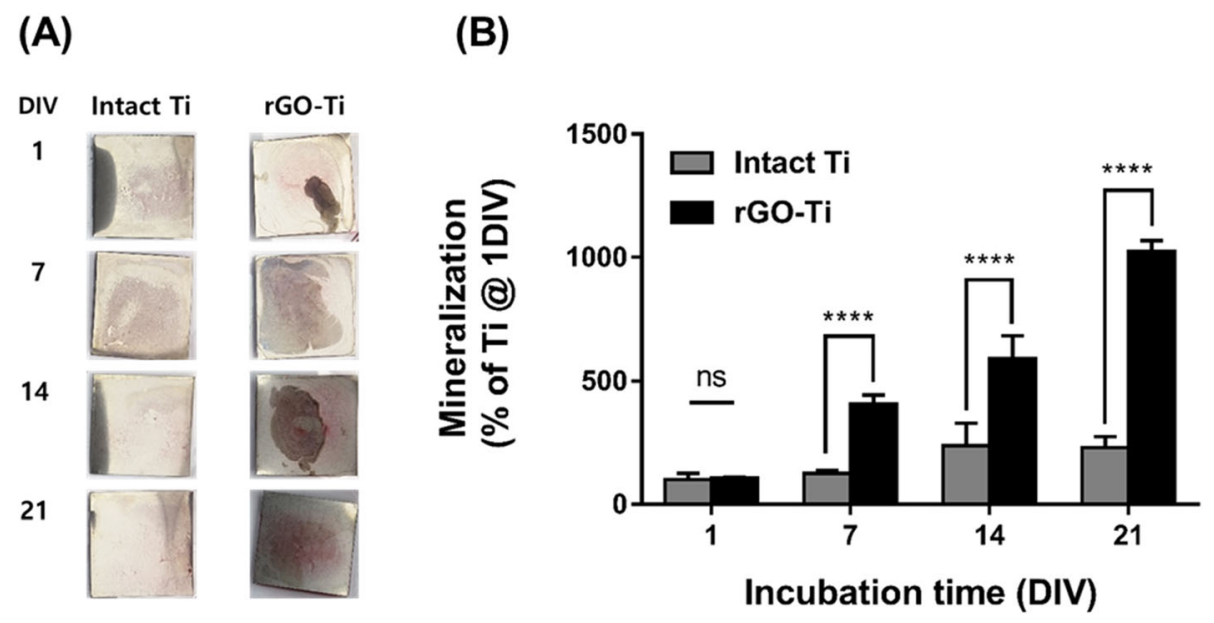

Fig. 6 Mineralization of hMSCs on intact Ti and rGO-Ti substrates. a Digital images of ARS stained hMSCs on intact Ti and rGO-Ti substrates and $\mathbf{b}$ Quantification of ARS staining. The results are shown as the mean \pm SD $\left(n=6\right.$, ns: not significant, $\left.{ }^{* * *}: p<0.0001\right)$

performance of cellular behaviors such as attachment, spreading, proliferation, and osteodifferentiation [62, 63].

For the cell study, the cell proliferation and osteogenic differentiation of hMSCs were examined on the rGO-Ti substrate. Even if the treatment concentration, cell type or culture conditions were different from this study, many related results demonstrated that rGO can induce positive effects on the proliferation of MSCs and preosteoblastic cells such as MC3T3-E1, hFOB, and MG63 cells [64-67]. This may be attributed to the osteogenic activity of $\mathrm{rGO}$, which is known to promote cell adhesion, spreading, and proliferation by supporting the protein adsorption and intracellular protein delivery by the ionic bonding formation and the electrical conductivity [68, 69]. In particular, graphene has a high affinity to dexamethasone, $\beta$-glycerolphosphate, and ascorbic acid contained in osteogenic media which are well-known osteogenic inducers [70]. It is known that dexamethasone could upregulate many proteins and enzyme levels concerning osteogenesis, hence elaborate calcium deposition [71]. Meanwhile, dexamethasone synergistically acts with $\beta$-glycerolphosphate to enhance the ALP activity level in the cells and ascorbic acid favorably affects the maturation of osteoblasts [72]. The exceptional high affinity would be ascribed to the $\pi-\pi$ stacking between aromatic rings of those biomolecules and the basal plane of graphene. Moreover, oxygen-containing moieties lead to electrostatic repulsion from phosphate ions and $\mathrm{OH}$ - moieties form hydrogen bonding to ascorbic acid [73]. Subsequently, it is suggested that the differentiation of hMSCs may be attributed to the affinity of rGO toward osteogenic differentiation-inducing factors such as cell essential ions and proteins. These observations, which could have general significance, demonstrate the potential of rGO-coated $\mathrm{Ti}$ substrates to promote the osteogenic differentiation of hMSCs.

\section{Conclusions}

Herein, rGO NPs were coated to the surface of Ti substrate using the MDD method to evaluate the osteogenic differentiation-inducing effect of prepared rGO-Ti substrates. rGO-Ti substrates not only enhanced the proliferation of hMSCs but promoted osteogenic differentiation of hMSCs. These results are mainly attributed to the specific characteristics of rGO such as structural defects, electrical conductivity, residual oxygen-containing moieties, and hydrophilic nature that lead to enhanced cell adhesion, protein adsorption from serum, and cell-cell or cell-matrix signaling. These positive effects finally led to the spontaneous differentiation of hMSCs. From these results, it is proved that the rGOTi substrates have the potential for bone differentiationinducing effect, therefore, promoting osseointegration with original tissue. In conclusion, it is suggested that the rGO-Ti substrates can be exploited to craft a range of strategies for the development of novel dental and orthopedic bone implants to accelerate bone regeneration because these graphene-coated materials have potentials to enhance osteogenesis.

\footnotetext{
Abbreviations

AFM: Atomic force microscopy; ALP: Alkaline phosphatase; ANOVA: Analysis of variance; ARS: Alizarin red S; ECM: Extracellular matrix; CCK-8: Cell counting kit-8; DMEM: Dulbecco's modified Eagle's Medium; GO: Graphene oxide; hMSCs: Human mesenchymal stem cells; MDD: Meniscus-dragging deposition; NPs: Nanoparticles; rGO: Reduced GO; SD: Standard deviation; Ti: Titanium
}

Acknowledgements Not applicable. 


\section{Authors' contributions}

MSK and SJJ carried out in-vitro experiments. MSK, SJJ, SHL, and BK participated in the fabrication of substrates. MSK, SJJ, SWH, and JHL prepared the original draft. MSK, SJJ, and DWH revised and edited the draft. DWH performed visualization, supervision, project administration, and funding acquisition. All authors read and approved the final manuscript.

\section{Funding}

This work was supported by the National Research Foundation of Korea (NRF) grant funded by the Korea government (MSIT) (No. 2016R1D1A1B03931076 and 2019R1A4A1024116) and a Korea Evaluation Institute of Industrial Technology (KEIT) grant funded by the Ministry of Trade, Industry, and Energy (MOTIE, Korea) (No. 20002010).

\section{Availability of data and materials}

All data generated or analyzed during this study are included in this published article.

\section{Ethics approval and consent to participate} Not applicable.

\section{Consent for publication}

Not applicable.

\section{Competing interests}

The authors declare that they have no competing interests.

\section{Author details}

'Department of Cogno-Mechatronics Engineering, College of Nanoscience \& Nanotechnology, Pusan National University, Busan 46241, South Korea. ${ }^{2} \mathrm{GS}$ Medical Co., Ltd., Cheongju-si, Chungcheongbuk-do 28161, South Korea. ${ }^{3}$ Department of Optics and Mechatronics Engineering, College of Nanoscience \& Nanotechnology, Pusan National University, Busan 46241, South Korea. ${ }^{4}$ Dental Life Science Research Institute / Innovation Research \& Support Center for Dental Science, Seoul National University Dental Hospital, Seoul 03080, South Korea. ${ }^{5}$ Daan Korea Corporation, Seoul 06252, South Korea.

\section{Received: 17 November 2020 Accepted: 4 February 2021}

\section{Published online: 12 February 2021}

\section{References}

1. Lee KY, Mooney DJ. Hydrogels for tissue engineering. Chem Rev. 2001;101: 1869-80.

2. Hollister SJ. Porous scaffold design for tissue engineering. Nat Mater. 2005;4: 518-24.

3. Madihally SV, Matthew HW. Porous chitosan scaffolds for tissue engineering Biomaterials. 1999;20:1133-42.

4. Shin H, Jo S, Mikos AG. Biomimetic materials for tissue engineering Biomaterials. 2003;24:4353-64.

5. Bose S, Vahabzadeh S, Bandyopadhyay A. Bone tissue engineering using 3D printing. Mater Today. 2013;16:496-504.

6. Zhao H, Ding R, Zhao X, Li Y, Qu L, Pei H, Yildirimer L, Wu Z, Zhang W. Graphene-based nanomaterials for drug and/or gene delivery, bioimaging and tissue engineering. Drug Discov Today. 2017;22:1302-17.

7. Amani $\mathrm{H}$, Mostafavi E, Arzaghi H, Davaran S, Akbarzadeh A, Akhavan O, Pazoki-Toroudi H, Webster TJ. Three-dimensional graphene foams: synthesis, properties, biocompatibility, biodegradability, and applications in tissue engineering. ACS Biomater Sci Eng. 2018;5:193-214.

8. Lee EJ, Lee JH, Shin YC, Hwang D-G, Kim JS, Jin OS, Jin L, Hong SW, Han DW. Graphene oxide-decorated PLGA/collagen hybrid fiber sheets for application to tissue engineering scaffolds. Biomater Res. 2014;18:18-24.

9. Shin YC, Kim J, Kim SE, Song S-J, Hong SW, Oh J-W, Lee J, Park J-C, Hyon SH, Han D-W. RGD peptide and graphene oxide co-functionalized PLGA nanofiber scaffolds for vascular tissue engineering. Regen Biomater. 2017;4 159-66

10. Kim H, Mondal S, Bharathiraja S, Manivasagan P, Moorthy MS, Oh J. Optimized Zn-doped hydroxyapatite/doxorubicin bioceramics system for efficient drug delivery and tissue engineering application. Ceram Int. 2018; 44:6062-71.
11. Albrektsson T, Brånemark P-I, Hansson H-A, Lindström J. Osseointegrated titanium implants: requirements for ensuring a long-lasting, direct bone-toimplant anchorage in man. Acta Orthop Scand. 1981;52:155-70.

12. Adya N, Alam M, Ravindranath T, Mubeen A, Saluja B. Corrosion in titanium dental implants: literature review. J Indian Prosthodont Soc. 2005;5:126.

13. Cook SD, Kay JF, Thomas KA, Jarcho M. Interface mechanics and histology of titanium and hydroxylapatite-coated titanium for dental implant applications. Int J Oral Maxillofac Implants. 1987;2:15-22.

14. Osman RB, Swain MV. A critical review of dental implant materials with an emphasis on titanium versus zirconia. Materials. 2015;8:932-58.

15. Hanawa T. Biofunctionalization of titanium for dental implant. Jpn Dent Sci Rev. 2010:46:93-101.

16. Elias C, Lima J, Valiev R, Meyers M. Biomedical applications of titanium and its alloys. Jom. 2008;60:46-9.

17. Wally ZJ, Van Grunsven W, Claeyssens F, Goodall R, Reilly GC. Porous titanium for dental implant applications. Metals. 2015;5:1902-20.

18. Liu $X$, Chu PK, Ding C. Surface modification of titanium, titanium alloys, and related materials for biomedical applications. Mater Sci Eng R. 2004:47:49-121.

19. Browne M, Gregson P. Surface modification of titanium alloy implants. Biomaterials. 1994;15:894-8.

20. Shen $H$, Zhang L, Liu M, Zhang Z. Biomedical applications of graphene. Theranostics. 2012;2:283.

21. Sun X, Liu Z, Welsher K, Robinson JT, Goodwin A, Zaric S, Dai H. Nanographene oxide for cellular imaging and drug delivery. Nano Res. 2008;1: 203-12.

22. Akhavan O, Ghaderi E, Emamy H. Nontoxic concentrations of PEGylated graphene nanoribbons for selective cancer cell imaging and photothermal therapy. J Mater Chem. 2012;22:20626-33.

23. Xu S, Zhan J, Man B, Jiang S, Yue W, Gao S, Guo C, Liu H, Li Z, Wang J. Realtime reliable determination of binding kinetics of DNA hybridization using a multi-channel graphene biosensor. Nat Commun. 2017:8:14902

24. Shin YC, Song S-J, Hong SW, Oh J-W, Hwang Y-S, Choi YS, Han D-W. Graphene-functionalized biomimetic scaffolds for tissue regeneration. Adv Exp Med Biol. 2018;1064:73-89.

25. Lee JH, Shin YC, Jin OS, Lee EJ, Han D-W, Kang SH, Hong SW, Ahn JY, Kim $\mathrm{SH}$. Cytotoxicity evaluations of pristine graphene and carbon nanotubes in fibroblastic cells. J Korean Phys Soc. 2012;61:873-7.

26. Lee JH, Shin YC, Lee S-M, Jin OS, Kang SH, Hong SW, Jeong C-M, Huh JB, Han D-W. Enhanced osteogenesis by reduced graphene oxide/ hydroxyapatite nanocomposites. Sci Rep. 2015;5:1-13.

27. Shin YC, Lee JH, Jin L, Kim MJ, Kim Y-J, Hyun JK, Jung T-G, Hong SW, Han DW. Stimulated myoblast differentiation on graphene oxide-impregnated PLGA-collagen hybrid fibre matrices. J Nanobiotechnology. 2015;13:21.

28. Lee JH, Shin YC, Jin OS, Kang SH, Hwang Y-S, Park J-C, Hong SW, Han D-W. Reduced graphene oxide-coated hydroxyapatite composites stimulate spontaneous osteogenic differentiation of human mesenchymal stem cells. Nanoscale. 2015;7:11642-51.

29. Kim SE, Kim MS, Shin YC, Eom SU, Lee JH, Shin D-M, Hong SW, Kim B, Park J-C, Shin BS. Cell migration according to shape of graphene oxide micropatterns. Micromachines. 2016:7:186-95.

30. Shin YC, Song S-J, Hong SW, Jeong SJ, Chrzanowski W, Lee J-C, Han D-W. Multifaceted biomedical applications of functional graphene nanomaterials to coated substrates, patterned arrays and hybrid scaffolds. J Nanomater. 2017:7:369-88.

31. Kang SH, Shin YC, Hwang EY, Lee JH, Kim C-S, Lin Z, Hur SH, Han D-W, Hong SW. Engineered "coffee-rings" of reduced graphene oxide as ultrathin contact guidance to enable patterning of living cells. Mater Horiz. 2019;6: 1066-79.

32. Shin YC, Song S-J, Lee JH, Park R, Kang MS, Lee YB, Hong SW, Han D-W. Different alignment between skeletal and smooth muscle cells on reduced Graphene oxide-patterned arrays. Sci Adv Mater. 2020;12:474-80.

33. Patel M, Moon HJ, Ko DY, Jeong B. Composite system of graphene oxide and polypeptide thermogel as an injectable 3D scaffold for adipogenic differentiation of tonsil-derived mesenchymal stem cells. ACS Appl Mater Interfaces. 2016:8:5160-9.

34. Lee WC, Lim CH, Su C, Loh KP, Lim CT. Cell-assembled graphene biocomposite for enhanced chondrogenic differentiation. Small. 2015;11: 963-9.

35. Shin YC, Kim C, Song S-J, Jun S, Kim C-S, Hong SW, Hyon S-H, Han D-W, Oh J-W. Ternary aligned nanofibers of RGD peptide-displaying M13 
bacteriophage/PLGA/graphene oxide for facilitated myogenesis Nanotheranostics. 2018;2:144-56.

36. Hong SW, Lee JH, Kang SH, Hwang EY, Hwang Y-S, Lee MH, Han D-W, Park J-C. Enhanced neural cell adhesion and neurite outgrowth on graphenebased biomimetic substrates. Biomed Res Int. 2014;2014:1-8.

37. Tatavarty R, Ding H, Lu G, Taylor RJ, Bi X. Synergistic acceleration in the osteogenesis of human mesenchymal stem cells by graphene oxidecalcium phosphate nanocomposites. Chem Commun. 2014:50:8484-7.

38. Lee SH, Shin YC, Jin OS, Han D-W, Kang SH, Hong SW, Kim JM. Enhanced neurite outgrowth of PC-12 cells on graphene-monolayer-coated substrates as biomimetic cues. J Korean Phys Soc. 2012;61:1696-9.

39. Shin YC, Lee JH, Kim MJ, Hong SW, Kim B, Hyun JK, Choi YS, Park J-C, Han D-W. Stimulating effect of graphene oxide on myogenesis of $\mathrm{C}_{2} \mathrm{C} 12$ myoblasts on RGD peptide-decorated PLGA nanofiber matrices. J Biol Eng. 2015;9:1-10.

40. Shin YC, Jin L, Lee JH, Jun S, Hong SW, Kim C-S, Kim Y-J, Hyun JK, Han D-W. Graphene oxide-incorporated PLGA-collagen fibrous matrices as biomimetic scaffolds for vascular smooth muscle cells. Sci Adv Mater. 2017;9:232-7.

41. Jin L, Lee JH, Jin OS, Shin YC, Kim MJ, Hong SW, Lee MH, Park J-C, Han D-W. Stimulated osteogenic differentiation of human mesenchymal stem cells by reduced graphene oxide. J Nanosci Nnotechnol. 2015;15:7966-70.

42. Park KO, Lee JH, Park JH, Shin YC, Huh JB, Bae J-H, Kang SH, Hong SW, Kim $B$, Yang DJ. Graphene oxide-coated guided bone regeneration membranes with enhanced osteogenesis: spectroscopic analysis and animal study. Appl Spectrosc Rev. 2016;51:540-51.

43. Shin YC, Song S-J, Jeong SJ, Kim B, Kwon IK, Hong SW, Oh J-W, Han D-W. Graphene-based nanocomposites as promising options for hard tissue regeneration. Adv Exp Med Biol. 2018;1078:103-17.

44. Zhao G, Qing H, Huang G, Genin GM, Lu TJ, Luo Z, Xu F, Zhang X. Reduced graphene oxide functionalized nanofibrous silk fibroin matrices for engineering excitable tissues. NPG Asia Mater. 2018;10:982-94.

45. Shin YC, Lee JH, Jin OS, Kang SH, Hong SW, Kim B, Park J-C, Han D-W. Synergistic effects of reduced graphene oxide and hydroxyapatite on osteogenic differentiation of MC3T3-E1 preosteoblasts. Carbon. 2015;95: $1051-60$.

46. Lee JH, Lee Y, Shin YC, Kim MJ, Park JH, Hong SW, Kim B, Oh J-W, Park KD, Han D-W. In situ forming gelatin/graphene oxide hydrogels for facilitated C2C12 myoblast differentiation. Appl Spectrosc Rev. 2016;51:527-39.

47. Lee JH, Lee S-M, Shin YC, Park JH, Hong SW, Kim B, Lee JJ, Lim D, Lim Y-J, Huh JB. Spontaneous osteodifferentiation of bone marrow-derived mesenchymal stem cells by hydroxyapatite covered with graphene nanosheets. J Biomater Tissue Eng. 2016;6:818-25.

48. Delgado A, Ahualli S, Fernández M, González M, Iglesias G, Vivo-Vilches J, Jiménez M. Geometrical properties of materials for energy production by salinity exchange. Environ Chem. 2017;14:279-87.

49. Wang Y, Shi Z, Yin J. Facile synthesis of soluble graphene via a green reduction of graphene oxide in tea solution and its biocomposites. ACS Appl Mater Interfaces. 2011;3:1127-33.

50. Wu J-B, Lin M-L, Cong X, Liu H-N, Tan P-H. Raman spectroscopy of graphene-based materials and its applications in related devices. Chem Soc Rev. 2018;47:1822-73.

51. Wang S, Wang R, Liu X, Wang X, Zhang D, Guo Y, Qiu X. Optical spectroscopy investigation of the structural and electrical evolution of controllably oxidized graphene by a solution method. J Phys Chem C. 2012; 116:10702-7.

52. Graf D, Molitor F, Ensslin K, Stampfer C, Jungen A, Hierold C, Wirtz L. Spatially resolved Raman spectroscopy of single-and few-layer graphene. Nano Lett. 2007;7:238-42.

53. Kim J-W, Shin YC, Lee J-J, Bae E-B, Jeon Y-C, Jeong C-M, Yun M-J, Lee S-H, Han D-W, Huh J-B. The effect of reduced graphene oxide-coated biphasic calcium phosphate bone graft material on osteogenesis. Int J Mol Sci. 2017; 18:1725-41.

54. Lee JJ, Shin YC, Song S-J, Cha JM, Hong SW, Lim Y-J, Jeong SJ, Han D-W, Kim B. Dicalcium phosphate coated with graphene synergistically increases osteogenic differentiation in vitro. Coatings. 2018;8:13-24.

55. Wrobel E, Leszczynska J, Brzoska E. The characteristics of human bonederived cells (HBDCS) during osteogenesis in vitro. Cell Mol Biol Lett. 2016;1: 26-33.

56. Xu C, Yang F, Wang S, Ramakrishna S. In vitro study of human vascular endothelial cell function on materials with various surface roughness. J Biomed Mater Res A. 2004;71:154-61.
57. Kunzler TP, Drobek T, Schuler M, Spencer ND. Systematic study of osteoblast and fibroblast response to roughness by means of surface-morphology gradients. Biomaterials. 2007;28:2175-82.

58. Zink C, Hall H, Brunette DM, Spencer ND. Orthogonal nanometermicrometer roughness gradients probe morphological influences on cell behavior. Biomaterials. 2012;33:8055-61.

59. Postiglione L, Di Domenico G, Ramaglia L, Montagnani S, Salzano S, Di Meglio F, Sbordone L, Vitale M, Rossi G. Behavior of SaOS-2 cells cultured on different titanium surfaces. J Dent Res. 2003;82:692-6.

60. Borsari V, Giavaresi G, Fini M, Torricelli P, Tschon M, Chiesa R, Chiusoli L, Salito A, Volpert A, Giardino R. Comparative in vitro study on a ultra-high roughness and dense titanium coating. Biomaterials. 2005;26:4948-55.

61. Kieswetter K, Schwartz Z, Hummert T, Cochran D, Simpson J, Dean D, Boyan B. Surface roughness modulates the local production of growth factors and cytokines by osteoblast-like MG-63 cells. J Biomed Mater Res. 1996;32:55-63.

62. Ku SH, Ryu J, Hong SK, Lee H, Park CB. General functionalization route for cell adhesion on non-wetting surfaces. Biomaterials. 2010;31:2535-41.

63. Shah S, Yin PT, Uehara TM, Chueng STD, Yang L, Lee KB. Guiding stem cell differentiation into oligodendrocytes using graphene-nanofiber hybrid scaffolds. Adv Mater. 2014;26:3673-80.

64. Jie W, Song F, Li X, Li W, Wang R, Jiang Y, Zhao L, Fan Z, Wang J, Liu B. Enhancing the proliferation of MC3T3-E1 cells on casein phosphopeptidebiofunctionalized 3D reduced-graphene oxide/polypyrrole scaffolds. RSC Adv. 2017;7:34415-24.

65. Mazaheri M, Akhavan O, Simchi A. Flexible bactericidal graphene oxidechitosan layers for stem cell proliferation. Appl Surf Sci. 2014:301:456-62

66. Mehrali M, Moghaddam E, Shirazi SFS, Baradaran S, Mehrali M, Latibari ST, Metselaar HSC, Kadri NA, Zandi K, Osman NAA. Synthesis, mechanical properties, and in vitro biocompatibility with osteoblasts of calcium silicatereduced graphene oxide composites. ACS Appl Mater Interfaces. 2014;6: $3947-62$.

67. Lim H, Huang N, Lim S, Harrison I, Chia C. Fabrication and characterization of graphene hydrogel via hydrothermal approach as a scaffold for preliminary study of cell growth. Int I Nanomedicine. 2011;6:1817-23.

68. Zhou K, Yu P, Shi X, Ling T, Zeng W, Chen A, Yang W, Zhou Z. Hierarchically porous hydroxyapatite hybrid scaffold incorporated with reduced graphene oxide for rapid bone ingrowth and repair. ACS Nano. 2019;13:9595-606.

69. Shi X, Chang H, Chen S, Lai C, Khademhosseini A. H. Wu: regulating cellular behavior on few-layer reduced graphene oxide films with well-controlled reduction states. Adv Funct Mater. 2012;22:751-9.

70. Scutt A, Bertram P, Bräutigam M. The role of glucocorticoids and prostaglandin E 2 in the recruitment of bone marrow mesenchymal cells to the osteoblastic lineage: positive and negative effects. Calcif. 1996:59:154-62

71. Haynesworth S, Goshima J, Goldberg V, Caplan A. Characterization of cells with osteogenic potential from human marrow. Bone. 1992;13:81-8.

72. Oshina H, Sotome S, Yoshii T, Torigoe I, Sugata Y, Maehara H, Marukawa E, Omura K, Shinomiya K. Effects of continuous dexamethasone treatment on differentiation capabilities of bone marrow-derived mesenchymal cells. Bone. 2007:41:575-83.

73. Lee WC, Lim CHY, Shi H, Tang LA, Wang Y, Lim CT, Loh KP. Origin of enhanced stem cell growth and differentiation on graphene and graphene oxide. ACS Nano. 2011;5:7334-41.

\section{Publisher's Note}

Springer Nature remains neutral with regard to jurisdictional claims in published maps and institutional affiliations.

\section{Ready to submit your research? Choose BMC and benefit from:}

- fast, convenient online submission

- thorough peer review by experienced researchers in your field

- rapid publication on acceptance

- support for research data, including large and complex data types

- gold Open Access which fosters wider collaboration and increased citations

- maximum visibility for your research: over $100 \mathrm{M}$ website views per year

At $\mathrm{BMC}$, research is always in progress.

Learn more biomedcentral.com/submission 